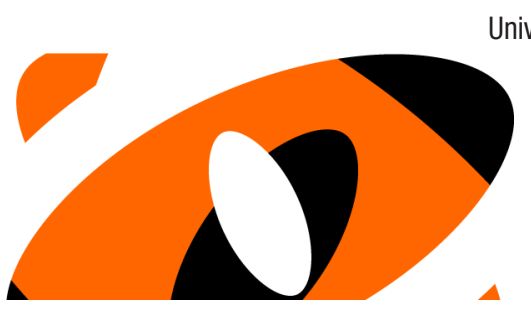

https://artnodes.uoc.edu

\title{
ARTICLE
}

NODE "ECOLOGY OF THE IMAGINATION"

\section{Researching imaginaries of the future as a tool for engendering grounded utopias for individual and social transformation and empowerment in educational environments}

\author{
Natàlia Cantó-Milà \\ Universitat Oberta de Catalunya \\ Mudhaffar Ali \\ High School College (Bielefeld University) \\ Amjad Bosata \\ High School College (Bielefeld University)

\section{Leshker Berho} \\ RWTH Aachen University, High School College (Bielefeld University)

\section{Sarmad Malla Ali} \\ RWTH Aachen University, High School College (Bielefeld University)

\section{Maria Mateo i Ferrer} \\ High School College (Bielefeld University) \\ Swen Seebach \\ Universitat Abat Oliba CEU
}

Date of submission: October 2020

Accepted in: January 2022

Published in: January 2022

\section{Recommended citation}

Cantó-Milà, Natàlia; Ali, Mudhaffar; Bosata, Amjad; Berho, Leshker; Malla Ali, Sarmad; Mateo i Ferrer, Maria; Seebach, Swen. 2022. «Researching imaginaries of the future as a tool for engendering grounded utopias for individual and social transformation and empowerment in educational environments». In: Garcés, Marina (coord.). «Ecology of the imagination» Artnodes, no. 29. UOC. [Accessed: dd/mm/yy]. https://doi.org/10.7238/artnodes.v0i29.393285 


\title{
artnodes
}

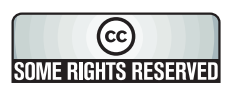

The texts published in this journal are - unless otherwise indicated - covered by the Creative Commons

Spain Attribution 4.0 International licence. The full text of the licence can be consulted here:

http://creativecommons.org/licenses/by/4.0/

\begin{abstract}
This article is the result of a shared collaborative research project between the Oberstufen-Kolleg Bielefeld, the faculty of pedagogy of the University of Bielefeld and a research group based at the Open University of Catalonia (Universitat Oberta de Catalunya). It presents and discusses a human, sociological and pedagogical project in participatory action research, in which we sought to follow Appadurai's call for research as a human right and put it into practice.

The article shares and analyzes a pedagogical practice in which the work with imaginaries was rendered an essential part of the educative process, becoming especially important for students who felt they were somehow excluded from full participation in social life. Furthermore, the article provides ideas about the relevance of putting imaginaries into participatory research, to relate society's members in shared research processes as well as the remarkable reciprocal effects that might result from these practices.
\end{abstract}

\section{Keywords}

participatory action research; imaginaries of the future; anticipation; pedagogy, emancipation

\section{Investigar los imaginarios de futuro como herramienta para engendrar utopías fundamentadas para la transformación y el empoderamiento individual y social en entornos educativos}

\section{Resumen}

Este artículo es el resultado de un proyecto de investigación compartido entre el Oberstufen-Kolleg Bielefeld, la facultad de pedagogía de la Universidad de Bielefeld y un grupo de investigación con sede en la Universitat Oberta de Catalunya. Presenta y discute un proyecto humano, sociológico y pedagógico de investigación-acción participativa, en el que intentamos seguir el llamamiento de Appadurai a la investigación como derecho humano y ponerlo en práctica.

El artículo comparte y analiza una práctica pedagógica en la que el trabajo con imaginarios se convirtió en una parte esencial del proceso educativo, cobrando especial importancia para los alumnos que se sentían de alguna manera excluidos de una participación plena en la vida social. Además, el artículo aporta ideas sobre la relevancia de incluir imaginarios en la investigación participativa, para relacionar a los miembros de la sociedad en procesos compartidos de investigación, así como sobre los notables efectos recíprocos que pueden derivarse de estas prácticas.

\section{Palabras clave}

investigación-acción participativa; imaginarios de futuro; anticipación; pedagogía, emancipación 


\section{artnodes} empowerment in educational environments

\section{Introduction}

This article is the result of shared collaborative research undertaken between the High School College Bielefeld (Oberstufen-Kolleg Bielefeld), the Faculty of Pedagogy of the University of Bielefeld, and the Faculty of Arts and Humanities of the Open University of Catalonia (Universitat Oberta de Catalunya). Or, to frame it in a more human-orientated way, it is the result of the collaboration of four high school students, their philosophy teacher and two sociologists. The four high school students, their experiences, questions, research and will to imagine and propose possible futures constitute the heart and soul of this research.

This project was originally proposed and developed by Cantó-Milà and Seebach at their respective universities, hence far from everyday life at a German high school. Inspired by Georg Simmel's sociology, particularly by the third apriority of the digression "How is Society Possible?" (2009, 49-52), this research was developed alongside the research question of whether, how, to what extent and under which circumstances, imaginaries of the future enable individuals to become full members of society. From this rather theoretical endeavour, a call for collaboration was published, in which high schools were addressed as potential collaboration partners in order to build a research team involving high school students and their teachers. Thus, the call for collaboration was an invitation to participate in the process of a co-creation of research. The High School College Bielefeld welcomed and embraced this call, and so our adventure began, between Barcelona and Bielefeld, in July 2018. This article deals with the research processes and results interwoven and produced during this collaborative venture, which began with a process of getting to know each other. The sociologists shared theoretical texts and research methods, and the High School College team set the agenda, discussed, dismissed, and added new texts and perspectives to the discussion while actively engaging in fieldwork.

Despite the fact that our joint venture is still unfolding, this article explores, presents, and discusses the research process that took place during the involvement and active participation of the first cohort of students, from July 2018 to July 2019.

\section{Framework}

Arjun Appadurai has claimed that research ought to be considered a human right. $(2013,282)$ He has argued for this right in a twofold way: on the one hand, he has claimed that it is time to deparochialize research, thus asserting the need to reclaim research as a capacity that should exist beyond university (and, we would add, beyond corporations, states, and other institutional settings). On the other hand, he has claimed that the capacity to carry out research is necessary for people to have full access to citizenship and to be able to fully participate in social, political, and economic life. A grounded capacity to conduct research enhances people's chances of pursuing their goals and thus paves the way towards the lives they seek to lead within their personal, socio-structural, and historical circumstances. Moreover, it allows them to work in an informed manner in order to change and shape present and future possibilities. The claim to this right is thus connected to the fact that the capacity to conduct research allows full "citizenship", and furthermore it is connected to what Appadurai has termed "the capacity to aspire." This capacity can only make sense if it is intrinsically linked with the capacity to be informed and to make sense of the information to which one has access. Without the ability to carry out research, without the capacity to gain, obtain and, above all, process and make sense of (new) information, the capacity to aspire turns into a trap of chimeras and despair. In Appadurai's terms:

"Without aspiration, there is no pressure to know more. And without systematic tools for gaining relevant new knowledge, aspiration degenerates into fantasy or despair. Thus, asserting the relevance of the right to research, as a human right, is not a metaphor. It is an argument for how we might revive an old idea - namely, that taking part in democratic society requires one to be informed. One can hardly be informed unless one has some ability to conduct research, however humble the question or however quotidian its inspiration. This is doubly true in a world where rapid change, new technologies, and rapid flows of information change the playing field for ordinary citizens every day of the week." (Appadurai 2013, 283).

Supporting young people in achieving this research competence should be a fundamental objective of education. Several decades before Appadurai's The Future as Cultural Fact, Paulo Freire also claimed that research not only allows us to understand reality, but also to problematize it and to open up the hope that makes transformative action possible. In other words, both Freire and Appadurai see two necessary conditions for empowerment and transformative action: on the one hand, a capacity to aspire (which Freire links to hope) and a grounded knowledge and profound understanding of one's context and situation, combined with an analytical competence and the capacity to process new information. Critical engagement and transformative action require an understanding of contexts, meanings and materialities of social reality, in order to be grounded. Only by being grounded can it shed light upon the reasons for people's needs, as well as for the social structures that condition them. It is in understanding these that the possibility of another reality opens up. This is why Freire talks about the pedagogy of hope in direct connection with the capacity to develop an analytical perspective, which can only be gained by introducing a certain distance, by not being "submerged in reality" any longer. In his own words:

"Individuals who were submerged in reality, merely feeling their needs, emerge from reality and perceive the causes of their needs." (Freire (1970)2005, 117).

To make this objective possible, education cannot be limited to transmitting knowledge to a passive pupil who is thus seen as an object (what Freire calls "banking education'). For Freire, education means educator 


\section{artnodes}

https://artnodes.uoc.edu

Researching imaginaries of the future as a tool for engendering grounded utopias for individual and social transformation and empowerment in educational environments

and pupils setting out together to discover reality. This is an understanding of education which conceives it as a practice of opening up questions rather than providing answers, which problematizes the state of things and thus opens up the possibility of another imaginable reality.

"Knowledge emerges only through invention and re-invention, through the restless, impatient, continuing, hopeful inquiry human beings pursue in the world, with the world, and with each other." (Freire (1970)2005, 72).

This way of understanding education, of providing knowledge by opening up to new questions and thinking and thereby creating a basis for hopeful engagement with the future, lays the foundations for collective forms of radical imagination (Castoriadis 2005) and a critical engagement with - and a possibility of thinking of - new paths towards the future. This is linked to what, more recently, Castro Varela and Vogelmann - using a concept of the German sociologist Oskar Negt have addressed in their writing. They point to the "capacity to utopia" (utopianism, or, in the original German, Utopiefähigkeit) as a process of actively opening up for discussion and working towards co-shaping our context(s):

"Utopianism means: not only believing in change, but also working towards neither accepting the "way things are' nor accepting to have to accept how they are. It means movement instead of rigidity, putting the "normal" up for discussion; it means permanent critique and self-criticism." (Castro Varela \& Vogelmann 1998, 243).

Appadurai's approach, as well as Freire's conceptualization of the practice of pedagogy, have guided the research that we present in these pages from its very beginning. But the authors of this article only became filled with life, embodied, and vibrantly real during the process of collaboratively unfolding the analysis of the imaginaries of the future of the young, and thereby creating a step towards utopia.

\section{Context}

Inspired by the works of Appadurai and Freire, as well as by the methodology of participatory action research, ${ }^{1}$ we developed a brief document containing several proposals for participatory research activities which could serve as a guide for a wider research collaboration between the project YoungFutures and high school students and their teachers. This document reached the High School College Bielefeld and became the guiding thread for a project-oriented workshop which Dr. Mateo i Ferrer offered her students in July 2018. As a result of this workshop (called "project weeks" at the High School College, which offers these pro- ject-base collaborative fortnight twice per school year, in January and July), our research journey began.

The first time the project "Imaginaries of the future" was offered by Dr. Mateo, a group of 20 students joined the project. From this original group, one young man was particularly interested in the topic. This student, Leshker Berho, asked Dr Mateo i Ferrer for a continuation of the research beyond the duration of the official project and its public presentation within the school. This petition, which came as a surprise to the whole research team, allowed us to imagine ways in which we could satisfy that demand for "more research". Furthermore, Leshker mentioned that he had been talking about the research, the project, his experiences and thoughts, and his need to further pursue the ideas and intuitions he had started to envision with other high school students and friends of his. He asserted that he was not the only one interested in granting continuity to the project and exploring the possibilities of conducting more research. In this way, the first cohort of researchers of this project was born. After inquiring at the school direction level, and encountering an enthusiastic response to the proposal, Dr. Mateo $i$ Ferrer offered Leshker the chance to engage in the organization of the next weeks of the project, and invited him to consider the possibility of building a team for that endeavour. In this way, in September 2018, a group of four young men began working on the proposal for a second edition of the project "Imaginaries of the future", and to spend some of their free time reading and discussing sociological and philosophical texts and preparing for the next project phase (which took place in January 2019). In order to make this engagement possible, Dr. Mateo and these four students travelled to Barcelona in October 2018 so as to be able to meet and discuss ideas, inquiries and doubts with members of the research team based in Barcelona. Those four students - Leshker, Amjad, Mudhaffar and Sarmad - assumed the role of research leaders, proposing and defining the directions that our debates took, and consequently also shaping the January project weeks offered at their school. They actively participated in the design of the content and dynamics of those January project weeks and were actively committed to engaging other students in our joint research - not as pupils, but as members of the research team. ${ }^{2}$

These four young men, who became the first team of engaged high school students in our shared project, shared more than just their high school and interest in our project. All four had been born in Syria (three were Kurds and spoke Kurdish as one of their mother tongues), and all had experienced the atrocities of the Syrian war during their transition from childhood to adolescence. With different stories of mobility and boundary crossing, their desire to study paved the way for them to finally meet at the Oberstufen-Kolleg Bielefeld.

1. Which for us is the only one that can actually embrace and dialogue with our reading of these two authors. See Fals Borda 1985, 2001; Reason \& Bradbury 2001.

2. About their experiences and reflections during this trip to Barcelona, the students published a text in the journal WE_OS-Jahrbuch 2018 with the title "Flight into an uncertain future". https:// www.biejournals.de/index.php/we os/issue/view/109.

The newspaper La Vanguardia also published an interview with them on 30 June 2019 with the title "Burying the refugee label": https://www.lavanguardia.com/vida/20190630/463179849526/ refugiados-siria-relato-testimonio-jovenes.html 


\section{artnodes}

https://artnodes.uoc.edu

Researching imaginaries of the future as a tool for engendering grounded utopias for individual and social transformation and empowerment in educational environments

When Leshker asked to pursue the research he had begun during his July project phase at school, he argued: "I have realised that this is what I needed to understand where I live now. It is not the language, or that people look or dress differently...It is that they imagine their futures in ways I don't understand, and perhaps they don't understand mine. I want to explore this in order to know more about this place where I live now. I want to do this in order to live better." (conversation/interview with Leshker, July 2018).

Leshker's clear statement that he thought that carrying out research allowed him to better understand his new surroundings and his life in them, and that this understanding would afford him a better quality of life, moved us deeply. It touched upon the two fundamental pillars we introduced above and which we have found in Freire and Appadurai: the capacity and will to aspire and hope, and the competence to perform research and process new information analytically and creatively. His engagement and enthusiasm were contagious, and we soon found ourselves deeply immersed in a continuous dialogue with these four young people, who took on the leadership role without hesitation as an opportunity to set the agenda of what mattered to them and interested them, both personally and theoretically. We tackled the challenge together, consciously in dialogue with Appadurai and Freire, and with a palpable capacity to (grounded) utopia. $^{3}$

Very soon, our discussions began to focus on two main issues: on the one hand, the importance of the possibility of having a future, and their strong willingness to focus on such a future rather than on the past they had experienced and with which they were trying to come to terms. On the other hand, an awareness (which they became increasingly able to verbalise as the project evolved) of the fact that the role that they felt everybody was expecting them to play in this future was the one of the "stranger': stranger in a new land, stranger in a new culture, stranger in their ways of moving, speaking, eating, thinking and being. There was something about this role they could not quite identify initially, but it was something that, in many ways, they felt was restricting their access to imagining, projecting, and desiring a future that welcomed them as individual people, not just as refugees. They verbalized the truth in the above quotation from Paulo Freire: they felt they were no longer "submerged in reality", but gaining a certain distance from their experiences and sorrows, along a capacity to understand what they were experiencing as well as to recognize how little the lenses through which many people and institutions in their new home looked at them really related to them as individuals, as human beings with hopes, dreams, and personal experiences.

\section{On ends and new beginnings}

We would now like to share a text that we composed together after our meeting in Barcelona in October 2019, and which we called "On Ends and New Beginnings" using the double meaning of ends (as goals, and as finishing points of something). It is not merely an analytical text, but is deeply rooted in the individual experiences of Leshker, Amjad, Mudhaffar and Sarmad. It is furthermore a text quite dear to us, as it captures a process which these four young men have depicted as having special importance to them; it contains, in their own words, "the results of our long journey to daring to aspire and understanding our new realities and experiences." (conversation/interview with Amjad, 2020):

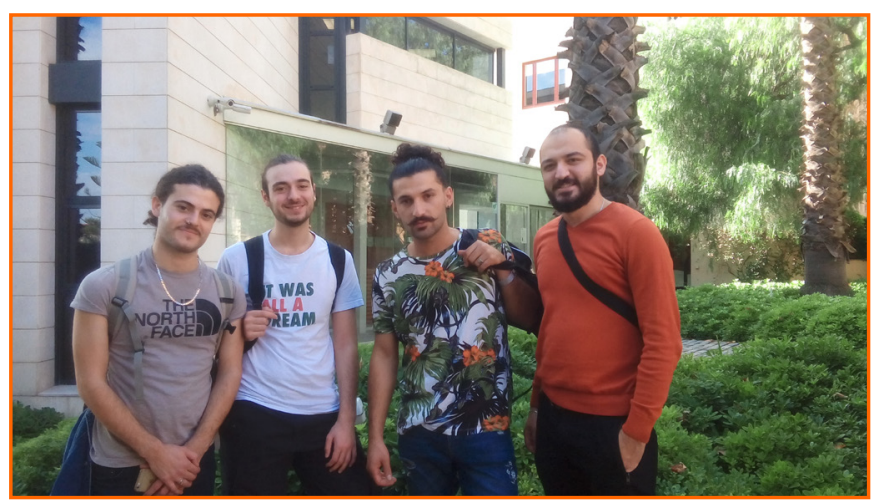

Figure 1: Arrival at UOC, Barcelona

Source: own creation

"Back in 2015 and 2016, four boys aged 15 to 17 embarked on a long journey. This journey began in different parts of Syria and ended in different parts of Germany. They undertook it alone or with their siblings. They crossed deserts, mountains, seas, and, most dangerous of all, manmade political borders on their way from Syria to Germany, enduring to a greater or lesser extent all kinds of difficulties. ${ }^{4}$ They made it to the end, bringing with them only themselves and one dream: safety and the chance to live in peace.

This one dream, one hope, kept them going throughout their journeys. However, once they arrived in Germany, the dream could carry them no further. They had made it. A new life in safety could begin. And yet, a sense of void began instead. For all four boys, who did not yet know each other, the same question arose: now what? ... and for what?

That which, throughout their journeys, had been their one and only goal, their end, had now become a beginning. The beginning of a new life they did not know how to live, or how to fill with purpose and meaning. Staying alive cannot be a young person's only objective. And when all those most immediate dangers are gone, but nothing has come to replace them, they realised, as if in a nightmare, that leaving

3. Which may sound as a contradiction, but after the references to Freire and Appadurai's thought, should be clear by now that it is not.

4. This is deliberately open and vague. Their journeys were different, some extremely harsh and dreadful, others safer and less terrifying. However, they will share the stories of those journeys whenever they decide to and however they decide to do it. It is not time yet. 


\section{artnodes}

https://artnodes.uoc.edu

Researching imaginaries of the future as a tool for engendering grounded utopias for individual and social transformation and empowerment in educational environments

the dangers behind does not bring their lives back to how they knew them. When they stopped focusing on staying alive another day, and another, and another, they began to focus on their surroundings. The unknown place they inhabited, how they were treated, those who were kind and hostile to and with them, what their hours and days could be filled with, and what they had left behind. Their families, their loved ones, their friends: a world in which they knew how to move, how to live, how to exist. But also, the futures they had thought lay ahead but that were now paradoxically behind them: university in Syria, their medical doctor careers in a safe Syria, their political causes, their trusted landscapes, the smells of the street markets, of the rain on the pavement, their favourite sweets.

When the team who authored this article met for the first time, the young men who signed this text were already students at the Oberstufen-Kolleg Bielefeld. They had the option to pass their university entrance exams (Abitur) and make it to university. However, this was not always a given for them, and the Oberstufen-Kolleg was not the first educational institution they had attended in Germany. When they arrived in the country, they all started their German educational path by enrolling in language courses. They knew that speaking German would be key to their present and future lives, and they engaged in learning the language with all their strength. This is not a given either, if we take into account the long journey, loneliness, and difficulties they had experienced along the way.

It is difficult to reconstruct what went on in their minds while trying to settle in and find a place in their new "home-to-be," but the idea of going back to school certainly belonged to their idea of mastering their new lives. This was the case for all of them but one, who - due to being Kurd - had never had access to a normal school life in Syria. Thus, what for the others meant a first step towards "normalization" of a new life, for this student was an extra challenge: getting used to an institution with which he was not acquainted, in a new place to which he was not accustomed, in a language he was fighting hard to master but was far from doing so.

For the other three young men, the project of going back to high school and pursuing their idea of one day perhaps attending university was, in a way, reconnecting with their pre-war past. It was a project that the three of them had brought with them from Syria, and which, despite all traumatic breaks and experiences and despite having lost all that which they had taken for granted as children, remained a project and a wish on their horizon. It became possible once they had made it to safety in Germany.

This safety was, however, relative: there was no war, of course, and they had made it to the end of their journey, which was a massive achievement considering the circumstances. However, the feeling of safety is linked to a certain capacity to know where you stand, to be able to anticipate some moves, to be acquainted with the rules of the game, and also, crucially, with a certain sense of autonomy. It is, furthermore, linked with a certain illusion of control - even if it is an illusion for us all in many senses, regardless of the more or less privileged circumstances of our lives. The feeling of knowing where we stand, and being in charge and in control of our lives, belongs to a certain sense of security. And all that was missing in the young men's first few months in Germany. Moreover, they had come to Germany on their own, without their parents, and they were teenagers facing life alone in a place they did not know and where they were not treated as equals, but as strangers, as refugees and as potentially dangerous people by the mere fact of where they came from and the insistent associations attached to these geographical origins.

Under these circumstances, clinging to the dream of studying felt at once like a foolish pipe dream, and like the most grounded and reasonable thing to do. And what may look like a paradox in writing, as a felt experience was full of an unspeakable coherence.

And it was at high school that they met. We could say it is a coincidence that so many young people from Syria met at the Oberstufen-Kolleg, but it is hardly so. Their applications to all other high schools were rejected (the "official" reason for their rejection was their age: they were older than regular students, which is hardly surprising given the circumstances). Only the Oberstufen-Kolleg Bielefeld (from now on, OS), an experimental high school in Westphalia, accepted them and offered them the chance to work hard for their university entrance exams (Abitur). They were given the chance to join Class 11 (the Abitur is taken in Class 13). Class 11, for new migrants and refugees who have not yet mastered the German language with enough proficiency to pursue their education pathway, lasts two academic years (instead of one). The first year is called the "enlarged initial phase" at this school (gestreckte Eingangsphase), which allows students to start learning the content and competencies ascribed to Class 11, while simultaneously taking their time to pair with these competencies the improvement of their German skills. This means that they can focus at a slower pace, while working on their language skills and school curricula.

It was while attending high school that these four young men who had left Syria as boys, and who had never met before arriving in Germany, came to know each other and became friends and confidants, helping and understanding each other (while teasing each other) in their new daily lives. Only two of them had met before joining the OS, having met at the halls of residence where they were temporarily living, and one of them was already a student at the OS. He told his new friend about his experience in joining the OS after so many rejections from other high schools, and his friend decided to apply as well. He was accepted. The other two young men applied separately, without being aware of the others" existence, and were also accepted.

Fortunately for all of us, they endured the shock of emptiness and apparently unbridgeable distance between "home" and "here and now'. However, it is important to emphasize that they were surrounded by many who could not cope with the emptiness and void of their new lives without meaning, in which their only goal was staying alive but living seemed to be out of reach. These four boys were able to bring one of their dreams back to life: studying at university, and slowly but steadily a journey began, and the object of this paper is to depict and analyze it." (Barcelona, October-November 2018) 


\section{artnodes} empowerment in educational environments

\section{From the imaginaries of the future to the foreigner... and back}

It was during their stay in Barcelona that Leshker, Amjad, Sarmad and Mudhaffar decided that they needed to come to terms with their "strangeness" in Germany, before they could really move on to refocusing on the imaginaries of the future, which for them were not an abstract and analytical object of study but a grounding, vital need: to be able to imagine a future for themselves in Germany, since the future they had anticipated since early childhood was destroyed, dead before ever being realized. The distance granted by theoretical texts, by the physical journey from Bielefeld to Barcelona, as well as the distance and understanding required to write the above text, were the first seeds of the articulation of the desire and need to shift their research towards the issue of "strangeness/being a stranger."

Specifically, it was while discussing Simmel's Sociology and, particularly, his digression on "How is Society Possible?" that these young students began to address the issue of their strangeness and their need to work and reflect upon it, to understand it in order to be able to cope with it: a desire to cope which became a desire for transformation. (Simmel, (1908)1992, 42-61; 2009, 601-620). In "How is Society Possible?" Simmel (2009: 40ff.) addressed three conditions, three "apriorities', which he presented as necessary for social relations to be procedurally interwoven in order to keep society alive, and be part of society. We will briefly focus on them, paying particular attention to the discussions that each "apriority" engendered.

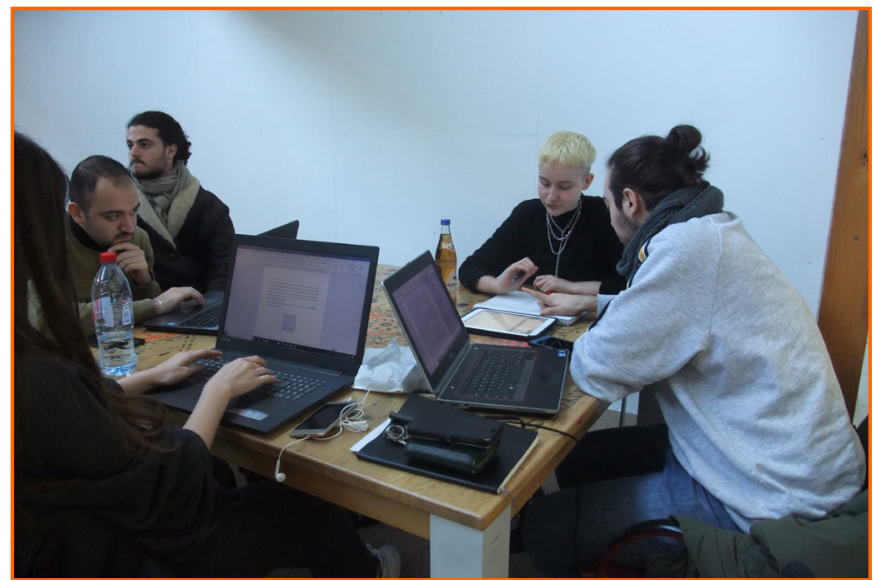

Figure 2: Work on projects during project week ZUsammenKUNFT, Bielefeld Source: own creation

1. The first condition for society to be possible, which Simmel formulated as an "apriority", claims that people can build wholes out of fragments, which means that they can typify and create complete pictures of living beings, surroundings and phenomena without having been able to comprehend or know them completely. This first condition addressed by Simmel focuses on the typification processes that we apply to all our experiences (we also build whole pictures/identities out of fragments of ourselves, not only of others). At a level of distant acquaintance, typification and stereotypification go hand-inhand. At this point, the four young men narrated how, in their everyday life, this "typification" and "stereotypification" was moving and touching them almost continuously. They verbalized how they felt "many eyes" on them, labelling them since their arrival in their new home, classifying them in categories with which they were unfamiliar. They verbalized how their physical traits, once so "normal", were "read" differently in their new context, and these traits evoked reactions in those who came in contact with them to which they were not accustomed. They addressed with concern the disgust, fear, anger and compassion they had encountered in their new home. Their descriptions were surprisingly close to Ahmed's conceptualization of the stickiness of certain meanings and associations attached to certain bodies, signs and objects, which lead people to certain emotional reactions. (Ahmed 2004, 13-15)

2. The second condition proposed by Simmel did not capture much attention in our discussion. It can be briefly summarized as the acknowledgement that human beings are more than social beings, and that this "more" co-forms their sociability in unutterable (i.e., non-social) ways.

3. The third condition, which is the spinal cord of our theorization of the imaginaries of the future, claims that people need to be able to envision a place for themselves in society, in order to be able to become fully socialized into these continuous reciprocal relationships that make up society. It was at this precise point that a unanimous question arose among the four students: how could they imagine themselves in any (other) place in society, when society was placing them in the role of strangers, foreigners, refugees? They verbalized the need to understand how and why the category of "refugee" had swallowed up their individuality.

As a reaction to this request, we incorporated the ninth chapter of Sociology into our reading list: particularly, the digression on "The Stranger", one of Simmel's best-known pieces. (Simmel, (1908)1992, 764-771) In order to work with this piece, we had to delve into the relational perspective that grounds Simmel's thoughts. We elaborated on how "strangeness" (i.e., the fact of "being" a stranger) is neither a characteristic one has nor something one is. It is nothing but a type of relation one is in. This idea immediately captured the group's attention: the fact that one is perceived, labelled and treated as a stranger, the fact that this "strangeness" sticks to oneself wherever one goes, seems to invite the thought that this strangeness must be something highly intrinsic to oneself. At the very least, it is the impression experientially created on a daily basis when this is the most salient characteristic one is told to have and treated as having. However, there is nothing "strange" about people labelled as "strangers". In fact, as soon as the relational 


\section{artnodes}

https://artnodes.uoc.edu

Researching imaginaries of the future as a tool for engendering grounded utopias for individual and social transformation and empowerment in educational environments

contexts in which they move change, their strangeness changes with them. Either they stop being strangers, or their strangeness increases or is redefined. This only happens because "being a stranger" is always a "being a stranger in relation to", and the relationship is the defining part of this strangeness. We are not strangers; we are in relationships that emphasize distances and overlook proximities, thus creating relational positions of "the stranger'.

This theoretical discussion and reading of Simmel had a liberating effect upon the group. The idea of finding, in a text written over a century ago, the answer to an urgent question and also a dialogue with a strong intuition that the four young men already had regarding their strangeness as having nothing to do with "the core of their being" (as one of them put it) had a momentarily liberating effect. And then the question arose: "If being a stranger is a form of shaping a relationship... Can we change it?"

In an interview published in the blog of the UOC Faculty of Arts and Humanities, Amjad Bosata commented on the possibilities of changing not only his situation as a foreigner/stranger, but also the hegemonic categories of normality from which his "strangeness" is defined. Bosata argued: "We often hear very negative things about our role in society, few people see us as capable of achieving anything. But talking among ourselves, if we explain everything we have learnt working with the UOC, we might be able to change something. And as there is undoubtedly a reciprocal relationship between our work and the work of the people around us, maybe that's how we can start to break down the wall that separates us from the rest of society. By working together." He added: "At first, when we claimed asylum in Germany, they gave us money to live on, a livelihood and allowed us to go to school. But they don't realise that this is not the most important thing to be able to play a positive role in the society that has taken us in. We want to actively participate in building it. And thanks to this project we are doing so. We do not want a separate "us" and "you". There is only one "us", because all of us together belong here, in the country where we are living now."

In this sentence, Amjad very clearly shows how theoretical reflection not only opens up hope for change, but also paves the way for making this change possible. This is an idea upon which Freire also insists, without ever assuming any automatism or simplicity in the process of giving birth to change: "This discovery cannot be purely intellectual but must involve action; nor can it be limited to mere activism but must include serious reflection: only then will it be a praxis." (Freire, $(1970) 2005,65)$

\section{January project weeks - "Coming together for the future"}

Back in Germany, Ali, Berho, Bosata and Malla organized the January project weeks with the support of their teacher Mateo i Ferrer, and called for any new students willing to enrol in the project. Sixteen students signed up, and together they continued to deepen the reflections on the imaginaries of the future under the perspective of being/feeling like strangers, analyzing and discussing this strangeness relationally. The project was welcomed by other students with great interest, as it became clear that this reflection also opened up the possibility of taking action to transform the reality that marginalizes those who feel like strangers (during these project weeks, we learned from the students the many ways in which young people can feel they are in a relationship of strangeness with the core of society). Through their collaborative work and engagement, the group of students decided to found an association, which they called ZUsammenKUNFT. This is a German word which, read as they write it, can be understood as either "coming together" or as "together for the future" or both. The aim of the association is to promote dialogue, coordinate different interests and publicize the work done in the project weeks and beyond in order to create a network of exchange.

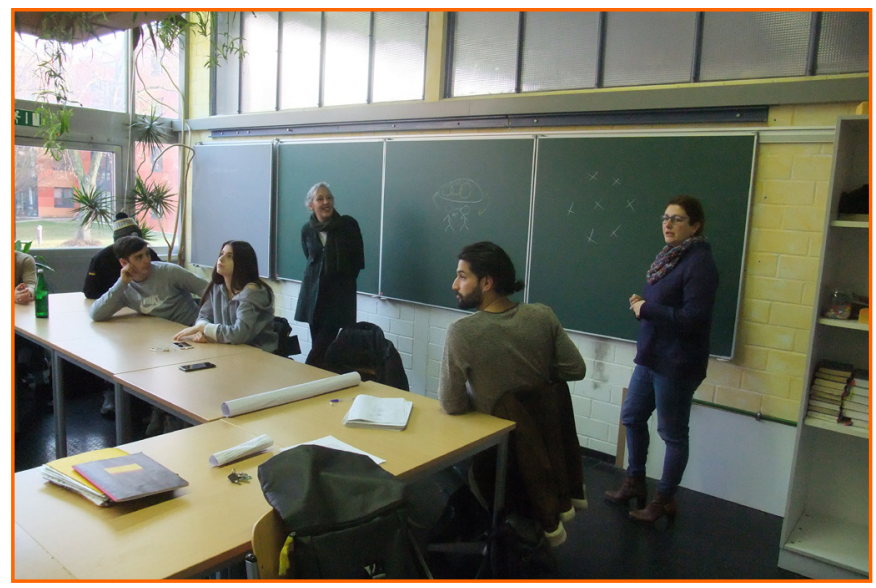

Figure 3: Project presentation at ZUsammenKUNFT, Bielefeld

Source: own creation

None of the young people who initiated this project are still at the Oberstufen-Kolleg. Each of them has followed a different path, but all are studying or about to start studying at university. Younger students have taken over the leading research role from the first team. Now, these younger students organize projects at a school level and travel to Barcelona to continue their training as researchers. The ZUsammenKUNFT association is still going strong, and more and more people are interested in this work; it is no longer just a school project. The association cooperates with a seminar of the Faculty of Education at the University of Bielefeld and partakes in conferences presenting the work of the team. ${ }^{5}$ They also cooperated with the international research project SOLIDARIS. In all these co-operations or presentations, it is the

5. Such as the one organised by the Faculty of Philosophy of the University of Bielefeld for philosophy teachers under the title Das Fremde in June $2021 \#$, or the one organised in March 2020 by the association SchlaU - Workshop for Migration Pedagogy in Munich. 


\section{artnodes}

https://artnodes.uoc.edu

Researching imaginaries of the future as a tool for engendering grounded utopias for individual and social transformation and empowerment in educational environments

students themselves who present their work and discuss their position and reflections with participants at the conferences. ${ }^{6}$

\section{Concluding Remarks}

In this article, we have argued for the importance of research in order to ground, inform, and thus allow the opening up and co-shaping of a place in society and the ability to project a future. We have also argued that the process of teaching, conducting and sharing research cannot be an exercise of "banking education." The capacity of "grounded utopia" requires a profound understanding of the circumstances in which one is immersed, so that they can be analyzed and opened up (analytically and also for discussion). In our case, and this is not a standard formula (of course), Simmel's texts - especially the two above-mentioned digressions - became a catalyst for active creative and collaborative thought, imagination, and research. They helped us in our process of working upon and understanding how categories of partaking and marginalization are interwoven and stabilized and how discourses are constructed that establish what is considered normal within a social context.

The critical engagement with imaginaries and the future, and the long exercise that led to the analysis of why the young researchers involved in this project "felt" like there was no place or future for them in their new home, has provided a strong framework for these researchers to gain a deeper understanding not only of their condition and status within society, but beyond those factors that turned them away from becoming full members of society.

Within this text, we believe we have shown that showing and engaging young people in research that helps them to understand the processes that are society as relational and dynamic, opens up the possibility of radical transformation (Castoriadis 2005), and with it, of hope for a better world (no universal claims intended, as it is always a situated vision and mission).

The right to research, as demanded by Appadurai, is important if we want to engage in this process of being/making/creating society as sovereign beings: a society that engages, and provides a place to, all its potential members. The knowledge that is transmitted at school is essential to this process of transformation and opening up society's black boxes. The theories that are learned are not capable of motivating transformative action if they are not accompanied by the hope that this transformation is possible, and by grounded experience and research regarding how to move forward. Participatory action research into imaginaries of future can provide that spark that can ignite a collective sense of hope and utopia. In this sense, Freire speaks of the "pedagogy of hope", Appadurai of the "capacity to aspire", Castro Varela and
Vogelmann of the capacity for utopia, and ourselves as "the capacity for (grounded) utopia" as the main competence to be transmitted by educational institutions.

\section{References}

Ahmed, Sara. The Cultural Politics of Emotion. Edinburgh: Edinburgh University Press, 2004.

Appadurai, Arjun. The future as cultural fact. Essays on the global condition. London: Verso, 2013.

Bourdieu, Pierre. Pascalian meditations. Stanford: Stanford University Press, 2000.

Cantó-Milà, Natalia, Seebach, Swen. «Desired images, regulating figures, constructed imaginaries: The future as an apriority for society to be possible». Current Sociology, vol. 63, no. 2 (2015): 198-215. DOI: https://doi.org/10.1177/0011392114556583.

Castoriadis, Cornelius. The imaginary institution of society. Cambridge: Polity Press, 2005.

Castro Varela, María, Vogelmann, Schulze. «Zwischen Allmacht und Ohnmacht - Überlegungen zur psychosozialen Beratung mit weiblichen Flüchtlingen». In: Castro Varela, M./ Schulze, S.Nogelmann, S./Weiß, A. (Hg.). Suchbewegungen. Interkulturelle Beratung und Therapie (1998): 233-246. Tübingen: dgvt.

Fals-Borda, Orlando. El problema de cómo investigar la realidad para transformarla: por la praxis. Bogotá: Tercer mundo, 1985.

Fals-Borda, Orlando. «Participatory (action) research in social theory: Origins and challenges». In: Reason, P., \& Bradbury, H. (eds.). Handbook of action research: Participative inquiry and practice (2001): 27-37. London: Sage.

Freire, Paulo. Pedagogy of the Oppressed. New York: Continuum, (1970) 2005. Reason, Peter, Bradbury, Hilary. (eds.). Handbook of action research: Participative inquiry and practice. London: Sage

Simmel, Georg. Soziologie: Untersuchungen über die Formen der Vergesellschaftung. Leipzig: Duncker \& Humblot, 1908.

Simmel, Georg. (2009). Sociology: Inquiries into the construction of social forms. Leiden: Brill. DOl: https://doi.org/10.1163/ ej.9789004173217.i-698.

6. Two articles describing this project and an example of how they work will appear in the WE_OS Jahrbuch $2021 .$. 


\section{artnodes}

https://artnodes.uoc.edu

Researching imaginaries of the future as a tool for engendering grounded utopias for individual and social transformation and empowerment in educational environments

CV

Natàlia Cantó-Milà

Universitat Oberta de Catalunya

ncantom@uoc.edu

She received her PhD (summa cum laude) in Social Sciences at the University of Bielefeld. She has taught sociology at the Universities of Bielefeld, Leipzig and at the Universitat Oberta de Catalunya. Her main fields of research are sociological theory, sociology of emotions and social imaginaries of the future. She is coordinator and member of the research group PROTCIS.

\section{Mudhaffar Ali}

High School College (Bielefeld University)

A Kurd from Syria who arrived in Germany alone in 2014. He will finish his baccalaureate in 2021 and is about to start his business studies at Bielefeld University.

\section{Amjad Bosata}

High School College (Bielefeld University)

He is from Syria. Arrived alone in Germany in 2014. He finished high school in 2020 and is now studying Teaching (secondary education) at the University of Bielefeld.

\section{Leshker Berho}

RWTH Aachen University, High School College (Bielefeld University)

A Kurd from Syria who arrived in Germany alone in 2014. He will finish his baccalaureate in 2021 and is about to start his business studies at Bielefeld University.

\section{Sarmad Malla Ali}

RWTH Aachen University, High School College (Bielefeld University)

He is a Kurd from Syria. He arrived in Germany alone in 2014. In 2020, he finished high school and is now studying engineering at the Technical University of Aachen.

\section{Maria Mateo i Ferrer}

High School College (Bielefeld University)

She obtained her PhD in Philosophy in 1998. She was born in Barcelona and has lived in Bielefeld since 1992. She has worked at the Faculty of Linguistics and Literature at the University of Bielefeld and since 2016 is working as a philosophy teacher at the Oberstufen-Kolleg of the University of Bielefeld, where she also conducts pedagogical research.

\section{Swen Seebach}

Universitat Abat Oliba CEU

sseebach@uao.es

Senior lecturer at Abat Oliba CEU University. In 2015, he received the prestigious Juan de la Cierva scholarship. In 2017, he published his book Love and Society with the editorial Routledge. In a current research project financed by the CEU Group and the Santander bank, he (as IP) and his research team focus on the link between emotions, future imaginaries, and emergencies. Seebach is a full member of the officially-recognized consolidated research group PROTCIS.

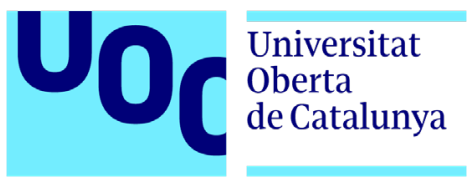

